\title{
ANALISIS DAYA TAMPUNG SUNGAI TERHADAP BEBAN PENCEMAR ORGANIK
}

\author{
ANALYSIS OF RIVER VACANCY FOR ORGANIC POLLUTION LOADS \\ Afresa Amanda ${ }^{1}$, Rony Riduan ${ }^{2}$, Chairul Abdi ${ }^{3}$ \\ Program Studi Teknik Lingkungan Fakultas Teknik ULM, \\ Jl. A. Yani Km.37, Banjarbaru, Kode Pos 70714, Indonesia \\ E-mail: afresaamanda96@gmail.com
}

\begin{abstract}
ABSTRAK
Pencemaran air Sungai Tapin disebabkan oleh adanya kebiasaan masyarakat yang bertempat tinggal di sekitar sungai untuk membuang limbah cair maupun limbah padatnya secara langsung sehingga akan berdampak terhadap perubahan kualitas air. Penelitian ini bertujuan untuk mengidentifikasi status mutu air sungai menggunakan metode Indeks Pencemar yang selanjutnya digunakan untuk analisis daya tampung beban pencemaran air dengan menggunakan metode Streeter Phelps yang dimodelkan dalam HEC-RAS. Pengukuran kualitas air Sungai Tapin dilakukan di 4 titik lokasi dan mempunyai status mutu tercemar ringan dengan nilai Indeks Pencemaran tertinggi sebesar 2,610 yang berada di titik 1, dan nilai terendah berada di titik sebesar 2,316. Berdasarkan hasil simulasi model kualitas air Sungai Tapin dengan menggunakan HEC-RAS konsentrasi DO dan BOD terbesar berada di titik 4 dan titik 1 yaitu sebesar 4,96 mg/l dan 1,29 mg/l. Setelah dilakukan pemodelan konsentrasi DO dan BOD diperoleh paling bagus pada simulasi ke 2 yaitu pada titik 1 dan 2 sebesar 8,50 mg/l dan $0,00972 \mathrm{mg} / \mathrm{l}$. Hasil konsentrasi kualitas air DO dan BOD digunakan untuk menentukan beban pencemaran dan daya tampung beban pencemaran Sungai Tapin sehingga diperoleh nilai beban dan daya tampung pencemaran model simulasi paling tinggi sebesar 1091,10 Kg/hari pada simulasi ke 2.
\end{abstract}

Kata kunci: DO, BOD, pencemaran, Daya Tampung

\begin{abstract}
Tapin River water pollution is caused by the habit of people who live around the river to dispose of liquid waste and solid waste directly so that it will have an impact on changes in water quality. This study aims to identify the status of river water quality using the Pollutant Index method which is then used to analyze the capacity of water pollution load using the Streeter Phelps method modeled in HECRAS. The measurement of Tapin River water quality was carried out at 4 location points and had a lightly polluted quality status with the highest Pollution Index value of 2.610 at point 1 , and the lowest value at the point of 2.316. Based on the simulation results of the Tapin River water quality model using HEC-RAS the highest DO and BOD concentrations were at point 4 and point 1 which were 4.96 $\mathrm{mg} / \mathrm{l}$ and $1.29 \mathrm{mg} / \mathrm{l}$. After modeling the DO and BOD concentrations were obtained best in the second simulation at points 1 and 2 at $8.50 \mathrm{mg} / \mathrm{l}$ and $0.00972 \mathrm{mg} / \mathrm{l}$. The results of the concentration of water quality DO and BOD were used to determine the pollution load and the capacity of Tapin
\end{abstract}


River pollution load so that the load value and pollution capacity of the simulation model were highest at $1091.10 \mathrm{Kg} /$ day in the second simulation.

Keywords: DO, BOD, pollution, Capacity

\section{PENDAHULUAN}

Sungai Tapin merupakan sumber daya air alami dan meliputi wilayah landskap daerah aliran air sungai yang terletak di Kabupaten Tapin Provinsi Kalimantan Selatan. Selama kurun waktu Tahun 2006 hingga sekarang di Kabupaten Tapin telah terjadi beberapa kegiatan yang telah mengakibatkan pencemaran lingkungan. Diantara kegiatan yang mendominasi adalah kegiatan penambangan pada areal tambang batu bara yang memberikan dampak terhadap meningkatnya pencemaran di sungai Tapin karena dilalui air limbah/lumpur dari areal tambang pada saat pembangunan, prossesing dan angkutan batu bara. Dampak lain akibat kegiatan tersebut yaitu sumber air baku yang biasa diolah PDAM untuk melayani kebutuhan air bersih masyarakat juga menjadi tercemar karena penurunan kualitas air. Kegiatan pemantauan kualitas lingkungan Tahun 2016 adalah dengan menghitung status mutu air yang diambil di titik lokasi pemantauan selama 5 periode. Hasil perhitungan status mutu air Sungai Tapin dengan Metode Indeks Pencemaran berdasarkan KepMen LH 115 Tahun 2013 yaitu cemar ringan dengan rentang skor $1<$ IP < 5,0 (Dinas Lingkungan Hidup Tapin, 2015).

Hasil pemantauan yang dilakukan oleh Dinas Lingkungan Hidup Kabupaten Tapin pada pada tanggal 17 Juli 2017 menunjukkan pencemaran di Sungai Tapin disebabkan oleh kebiasaan masyarakat yang berdomisili di sekitar sungai untuk membuang limbah cair dan limbah padat hasil buangan limbah rumah tangga langsung dibuang ke sungai. Hal tersebut ditunjukkan dengan nilai DO Desa Bungur yang rendah 4,2 mg/l dan BOD sebesar 1,045 mg/l, sedangkan nilai DO, dan BOD Sungai Tapin Desa Perintis Raya yaitu 4,3 mg/l, 5,925 mg/l. Menurut Peraturan Gubernur Kalimantan Selatan No. 05 Tahun 2007 tentang baku mutu air sungai yang diperuntukkan untuk kelas I, air Sungai Tapin masih belum sesuai dengan peruntukan karena mempunyai kandungan beban pencemar organik yang tinggi (Dinas Lingkungan Hidup Tapin, 2017). Rendahnya nilai DO dan tingginya nilai BOD yang belum memenuhi baku mutu air kelas I disebabkan karena pembuangan limbah secara langsung berkontribusi untuk meningkatkan pencemaran badan sungai (Mulla \& Bhosale, 2015). Karena permasalahan tersebut perlu adanya upaya dalam melakukan pengelolaan kualitas dan pengendalian pencemaran air sungai dengan menerapkan model untuk analisis kualitas air menggunakan program HEC-RAS. Model kualitas air akan cukup penting sebagai alat untuk mengetahui daya tampung sungai dalam jangka panjang yang dapat digunakan untuk mengembangkan perencanaan serta pengelolaan yang terukur terhadap sumberdaya air di sebuah Daerah Aliran Sungai (DAS) (Marganingrum, Djuwansah, \& Mulyono, 2018).

Progam HEC RAS merupakan paket program yang dirancang untuk membuat simulasi aliran satu dimensi. Salah satu komponen yang ada dalam HEC-RAS adalah dapat digunakan untuk analisis hitungan kualitas air, menggunakan komponen Water Quality Analysis yang dapat dipakai untuk melakukan analisis beberapa parameter kualitas air seperti, Dissolved Oxygen (DO) dan Carbonaceous Biological Oxygen Demand (BOD) (Istiarto, 2014). Model tersebut umumnya dibangun berdasarkan model dasar yang dikembangkan oleh Streeter Phelps yang kemudian dikenal sebagai persamaan Oxygen Sag Streeter Phelps (C.C Lee et al, 2000; Marganingrum et al., 2018). Penggunaan pemodelan 
dengan program HEC-RAS. Hasil penelitian dari Allbab, Dermawan, \& Harisuseno (2015) menggunakan program HEC-RAS dapat memodelkan kadar sebaran DO. Sehingga dapat disimpulkan bahwa hasil dari penggunaan model tersebut dapat memberikan dasar untuk memilih upaya pengurangan beban pencemaran yang sesuai.

Mengacu pada pemikiran di atas, maka penelitian yang ingin dilakukan adalah tentang analisis daya tampung air Sungai Tapin mengingat pentingnya kualitas air dalam kehidupan ekosistem sungai. Karena tingkat pencemaran sungai yang semakin tinggi dapat melampaui daya tampung sungai tersebut. Penelitian ini bertujuan untuk dijadikan Informasi penting dalam upaya pengelolaan konservasi lingkungan perairan setempat serta dapat dijadikan sebagai pengambilan keputusan dalam hal pengelolaan sumber-sumber pencemar yang ada di wilayah aliran Sungai Tapin.

\section{METODE PENELITIAN}

\subsection{Lokasi dan Waktu Penelitian}

Penelitian ini dilaksanakan di 4 titik di Desa Bungur, Kupang Surgirama, Kupang Jembatan Kilat dan Perintis Raya pada tanggal 8 Agustus 2018. Lebih jelasnya dapat dilihat pada peta lokasi penelitian sebagai berikut:
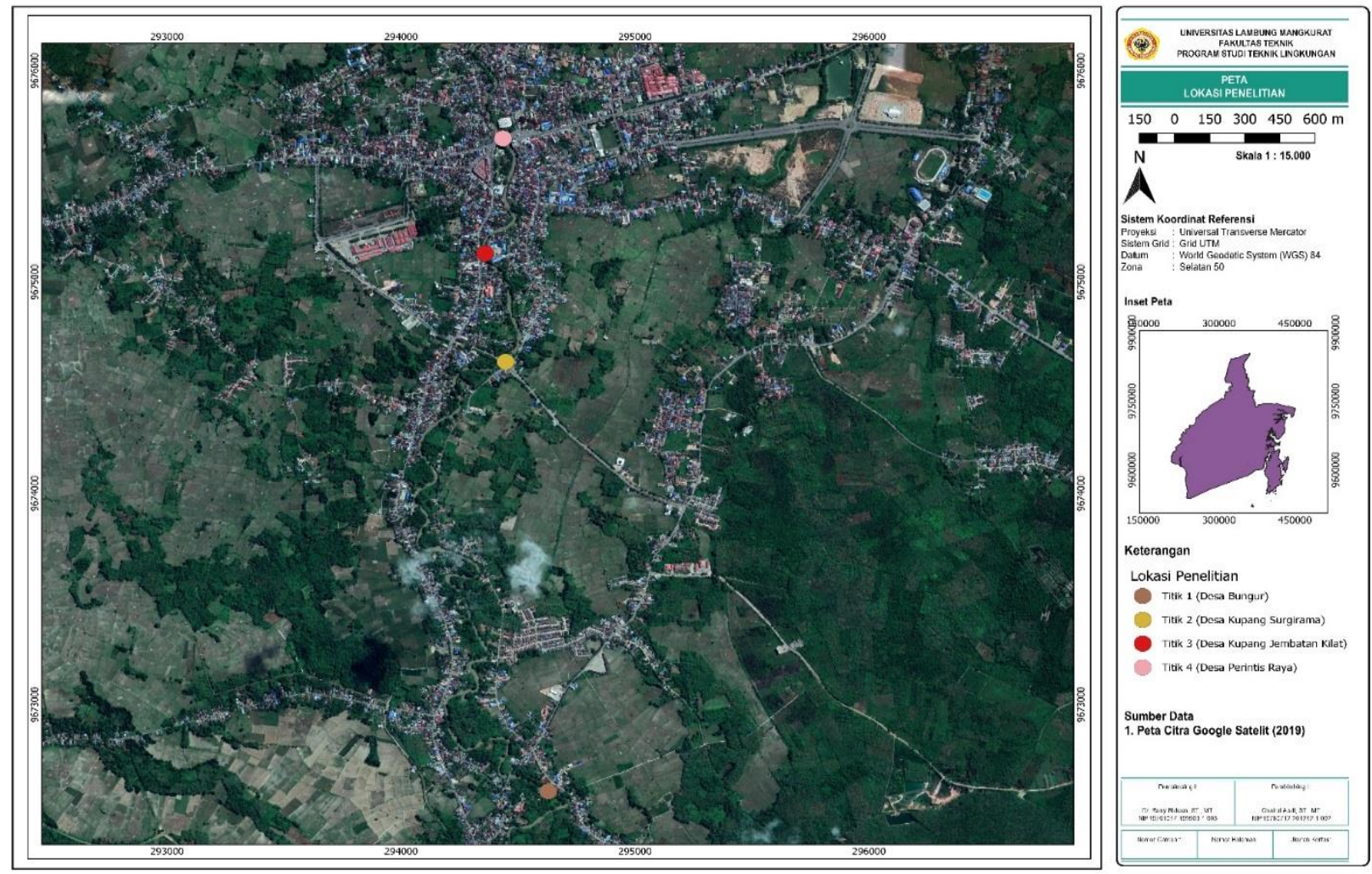

Gambar 1. Lokasi Penelitian 


\subsection{Alat dan Bahan Penelitian}

Alat yang digunakan pada penelitian ini berupa GPS, thermometer, current meter, water depth, $\mathrm{pH}$ meter, conductivity meter, botol putih, cool box, dan meteran. Bahan yang dibutuhkan pada penelitian ini yaitu air sungai untuk sampel pengujian laboratorium, pengawet sampel air berupa $\mathrm{H}_{2} \mathrm{SO}_{4}$, larutan $\mathrm{pH} 9$ dan bahan kimia untuk analisis parameter uji BOD.

\subsection{Rancangan Penelitian}

Penelitian ini memiliki tiga tahapan pelaksanaan. Tahap pertama adalah studi literatur dan survey pendahuluan, dalam tahap survey pendahuluan dilakukan penentuan titik lokasi pengambilan sampel kualitas air berdasarkan "SNI 6989:57,2008" yaitu:

a. Sumber air alamiah, yaitu pada lokasi yang belum atau sedikit terjadi pencemaran (titik 1 pada Gambar 2.3).

b. Sumber air tercemar, yaitu pada lokasi yang telah menerima limbah (titik 4 pada Gambar 2.3).

c. Sumber air yang dimanfaatkan, yaitu pada lokasi tempat penyadapan sumber air tersebut (titik 2 dan 3 pada Gambar 2.3).

d. Lokasi masuknya air ke waduk atau danau (titik 5 pada Gambar 2.3).

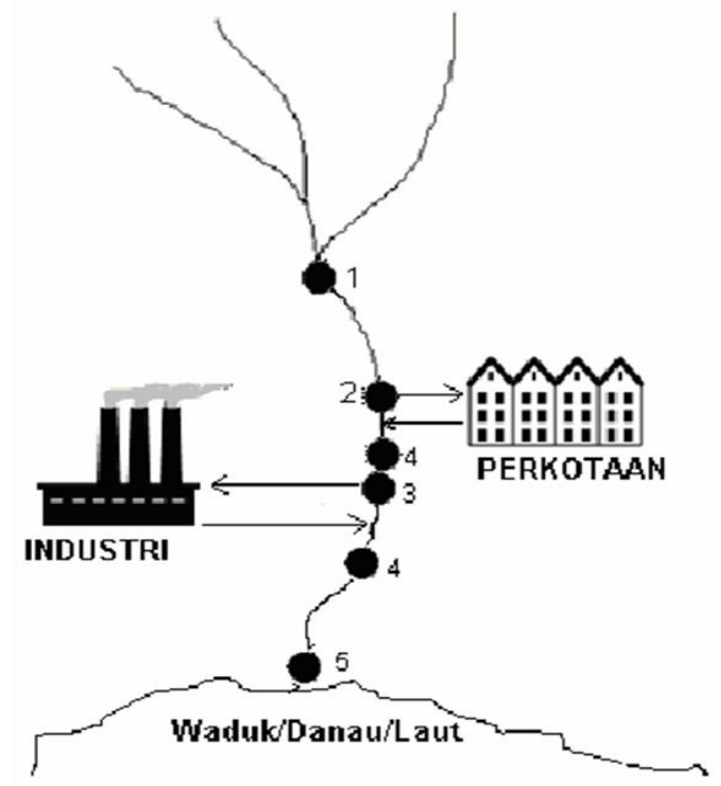

Keterangan gambar:

1) Sumber air alamiah

2) Sumber air untuk perkotaan

3) Sumber air untuk industri

4) Sumber air yang sudah tercemar

5) Lokasi masuknya air ke danau atau waduk

Sumber: SNI 6989:57, 2008

Gambar 2. Contoh Lokasi Pengambilan Air

Penelitian ini dimulai dengan tahapan mengumpulkan dan mempelajari pustaka yang ada kaitannya dengan penelitian yang dilakukan pada skala lapangan dan analisis laboratorium, adapun tujuannya adalah untuk mengetahui mutu air sungai dengan menggunakan metode Indeks Pencemaran agar dapat mengetahui besaran daya tampung Sungai Tapin. Penentuan lokasi pengambilan titik sampel untuk melakukan pengukuran kualitas air didasarkan pada debit rerata tahunan dan klasifikasi sungai (Hadi, 2015). Adapun variabel yang dipilih sebagai variabel bebas adalah DO dan BOD sedangkan variabel terikat yaitu daya tampung sungai dan data nutrient dalam air seperti parameter nitrat, nitrit, alga dan fosfat serta data klimatologi di wilayah Kabupaten Tapin. Kegiatan pengumpulan data dibagi menjadi 
dua yaitu data primer dan data sekunder seperti data kualitas air selama 5 Tahun terakhir yaitu 20142018, data debit sungai, data meteorologi (curah hujan, kelembaban udara, suhu udara, kecepatan angin, dan intensitas penyinaran matahari) serta data geografi sungai seperti letak sungai yang mencakup data lintang dan bujurnya. Sedangkan data primer yang dikumpulkan yaitu data hidrologi sungai (panjang sungai, lebar sungai, debit sungai, kecepatan aliran sungai dan kedalaman sungai), data kualitas air sungai untuk proses kalibrasi dan validasi. Setelah data semuanya terkumpul kemudian barulah dilakukan input data untuk pembuatan model dengan menggunakan program HEC-RAS dengan menggunakan metode streeter phelps yang dilanjutkan dengan simulasi model untuk memperoleh kualitas mutu air sungai dengan tujuan untuk rekomendasi pengendalian pencemaran. Sehingga dapat dilakukan analisis perhitungan daya tampung yang sesuai dengan kelas baku mutu sungai.

\subsection{Analisis Data}

Analisis data dilakukan dengan menggunakan model kualitas air yaitu metode Streeter Phelps yang kemudian dijelaskan secara deskriptif untuk mengetahui hasil pengukuran kemudian dibandingkan dengan baku mutu "Peraturan Gubernur Kalimantan Selatan no 05 tahun 2007 tentang Baku Mutu Air Sungai".

\section{Hasil dan Pembahasan}

\subsection{Status Mutu Air Sungai Tapin}

Penelitian ini menggunakan perhitungan indeks pencemaran yang didasarkan pada setiap titik pengambilan sampel dan parameter yang telah ditentukan yaitu DO dan BOD dengan parameter pendukung yaitu suhu, DHL, pH dan COD. Baku mutu air yang digunakan adalah baku mutu Kelas I berdasarkan Peraturan Gubernur Kalimantan Selatan Nomor 05 Tahun 2007 tentang Peruntukan dan Baku Mutu Air Sungai. Hasil perhitungan indeks pencemaran pada masing-masing titik pengambilan sampel terdapat pada Tabel 3.1 sebagai berikut.

Tabel 3.1 Hasil Perhitungan Indeks Pencemaran Sungai Tapin Tahun 2018

\begin{tabular}{crrr}
\hline \multirow{2}{*}{ No } & \multirow{2}{*}{ Titik Pengambilan Sampel } & \multicolumn{2}{c}{ Indeks Pencemaran } \\
\cline { 3 - 4 } & & \multicolumn{2}{c}{ Kelas I } \\
\hline 1 & 1 (Desa Bungur) & 2.610 & Cemar Ringan \\
2 & 2 (Desa Kupang Surgirama) & 2.316 & Cemar Ringan \\
3 & 3 (Desa Kupang Jembatan Kilat) & 2.552 & Cemar Ringan \\
4 & 4 (Desa Perintis Raya) & 2.517 & Cemar Ringan \\
\hline
\end{tabular}

Berdasarkan hasil perhitungan indeks pencemaran pada Tabel 3.1 dapat disimpulkan bahwa kualitas air Sungai Tapin Tahun 2018 dari arah hulu (Desa Bungur) ke arah hilir (Desa Perintis Raya) mengalami fluktuasi atau cenderung mengalami penurunan kualitas yang dapat dilihat dari nilai indeks pencemaran. Pencemaran air sungai terjadi karena disebabkan rendahnya kadar DO yang tidak memenuhi baku mutu dan tingginya kadar pH, BOD dan COD sehingga melebihi ambang batas Kelas I yang telah ditetapkan melalui Peraturan Gubernur Kalsel No.05 Tahun 2007 dengan masing-masing 
baku mutu yang dimiliki yaitu DO (>6 mg/l), pH (deviasi 3), BOD (2 mg/l) dan COD (10 mg/l). Sehingga berdasarkan Peraturan Gubernur tersebut dengan kondisi kualitas air Sungai Tapin yang sudah tercemar ringan tidak dapat dimanfaatkan sebagai air baku untuk air minum tetapi masih dapat dimanfaatkan untuk kegiatan rekreasi, budidaya ikan air tawar, peternakan dan mengairi tanaman dengan nilai kualitas yang masih memenuhi baku mutu. Kondisi status mutu air Sungai Tapin pada Tahun 2018 dapat dijadikan sebagai bahan evaluasi untuk upaya pengendalian pencemaran air sungai dan untuk mengembalikan kualitas air agar dimanfaatkan sesuai dengan peruntukkannya. Oleh sebab itu, perlu dilakukannya lebih lanjut pengendalian pencemaran atau kajian tentang penyebab rendahnya nilai DO dan tingginya nilai BOD air Sungai Tapin yang dihasilkan.

\subsection{Pembuatan Model DO}

Parameter DO digunakan sebagai data untuk melakukan simulasi menggunakan HEC-RAS berdasarkan kondisi hidrolika, kualitas nutrien air sungai dan meteorologi di lokasi penelitian. Pembuatan model diawali dengan memasukkan data dalam program HEC-RAS yaitu membuat projek baru yang dinamai sesuai dengan kebutuhan, selanjutnya adalah membuat peniruan geometri saluran atau air sungai yang diikuti dengan peniruan jenis aliran sungain yang berupa aliran steady flow. Pada program ini data kualitas air diinput dengan memilih menu utama "edit water quality boundary conditionI" serta pilihan koefisien kualitas air untuk menjalankan program. Hasil dari simulasi kualitas air parameter DO perlu dilakukan tahap kalibrasi yang ditentukan oleh koefisien dari masing masing parameter dengan cara memasukkan nilai dari $\mathrm{K}_{1}$ (Decay Rate) dan $\mathrm{K}_{2}$ (Atmospheric Reaeration) pada lembar kerja nutrient parameters. Hal ini bertujuan untuk menyamakan hasil simulasi model parameter DO dengan hasil pengukuran di lapangan. Data hasil pengukuran dan data hasil pemodelan HEC-RAS menunjukkan besar konsentrasi DO di Sungai Tapin sama-sama berasal dari sumber pencemar limbah kegiatan domestik dan MCK masyarakat. Sehingga pada simulasi HEC-RAS tidak perlu dilakukan tahap kalibrasi dengan mengubah koefisien yang sesuai. Hal ini disebabkan simulasi ini mendekati hasil konsentrasi DO pada pengukuran di lapangan. Setelah proses kalibrasi kualitas air maka dilanjutkan dengan simulasi skenario kualitas air. Pada hasil pemodelan ini dilakukan validasi untuk membandingkan antara hasil pemodelan menggunakan HEC-RAS dengan nilai hasil pengukuran di lapangan. Validasi dilakukan menggunakan metode Root Mean Square Error (RMSE) untuk menunjukkan hasil dari pemodelan dengan hasil yang akan dimodelkan. Perhitungan dengan program HEC-RAS dapat dilihat pada Tabel 3.2. Lokasi yang digunakan untuk memvalidasi model adalah lokasi yang dekat dengan pengukuran langsung.

Tabel 3.2 Hasil Pengukuran dan Perhitungan HEC-RAS Konsentrasi DO

\begin{tabular}{cccc}
\hline $\begin{array}{c}\text { Waktu } \\
\text { Pengamatan }\end{array}$ & $\begin{array}{c}\text { Titik Lokasi } \\
\text { Pengamatan }\end{array}$ & $\begin{array}{c}\text { Hasil Pemodelan } \\
(\mathbf{m g} / \mathbf{l})\end{array}$ & $\begin{array}{c}\text { Hasil Pengukuran } \\
(\mathbf{m g} / \mathbf{l})\end{array}$ \\
\hline \multirow{2}{*}{8 Agustus 2018} & 1 & 4.39 & 3.69 \\
& 2 & 4.74 & 4.25 \\
$(09.00-11.10$ & 3 & 4.88 & 3.88 \\
WITA) & 4 & 4.96 & 3.87 \\
\hline Root Mean Square Error (RMSE) & \multicolumn{3}{|c}{0.087} \\
\hline
\end{tabular}

Berdasarkan Tabel 3.2 terlihat hasil pemodelan di titik 1 sebesar 4,39 mg/l sedangkan hasil pengukurannya sebesar 3,69 mg/l, titik 2 terlihat hasil dari pemodelan sebesar 4,74 mg/l sedangkan 
hasil pengukurannya sebesar 4,25 mg/l. Hasi model di titik 3 adalah sebesar 4,88 mg/l sedangkan hasil dari pengukurannya sebesar 3,88 dan titik ke 4 yang paling hilir mempunyai nilai hasil model sebesar 4,96 mg/l sedangkan hasil pengukurannya sebesar 3,87 mg/l. Sehingga validasi model ini diperoleh nilai RMSE 0.087 yang menunjukkan bahwa model sudah akurat. Adapun kondisi simulasi konsentrasi DO merupakan simulasi yang sesuai dengan kondisi eksisiting saat Tahun 2018, dimana data yang diinput sesuai dengan hasil dari pembentukan model. Lalu dilakukan running pada program HEC-RAS. Dalam penelitian ini hanya dilakukan perhitungan model pada pagi hari.

Model kualitas air yang telah dibuat dengan software HEC-RAS versi 5.0.3 dapat dipergunakan untuk mengestimasi kualitas air dengan skenario yang dikehendaki. Proses mengestimasi kualitas air menggunakan model ini disebut simulasi. Parameter kualitas air yang disimulasi adalah DO, adapun simulasi kualitas air Sungai Tapin dilakukan sebanyak 2 skenario dengan asumsi debit, kualitas air di hulu (Desa Bungur), kondisi sumber pencemaran, dan kualitas air di sepanjang sungai. Simulasi skenario 1 dilakukan dengan menggunakan kondisi sumber pencemaran hasil dari pemodelan yaitu data air limbah dan sumber pencemar lainnya berdasarkan data Tahun 2018. Simulasi ini dimaksudkan untuk mengetahui pengaruh sumber pencemaran eksisting terhadap kualitas air sungai di setiap titik hingga hilir. Hasil simulasi skenario 1 dapat dilihat pada gambar 3.

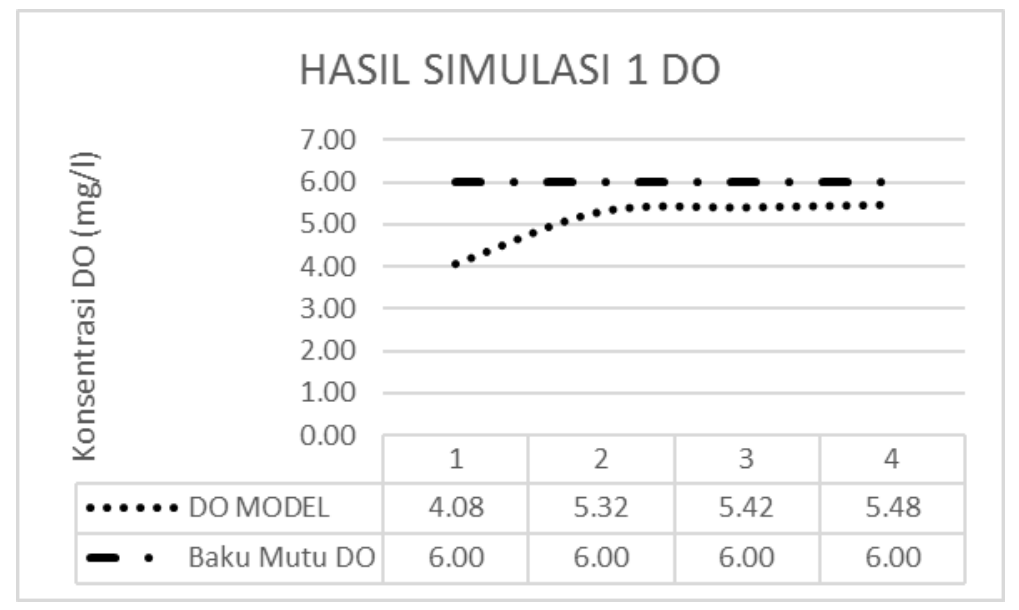

Gambar 3. Hasil Simulasi 1 DO

Berdasarkan hasil analisis konsentrasi DO pada hasil model dan simulasi 1 yang menunjukkan peningkatan tetapi kualitas air sungai untuk parameter DO tidak memenuhi baku mutu air kelas I. Peningkatan konsentrasi DO menandakan bahwa air Sungai Tapin telah mengalami pengurangan beban pencemaran limbah oleh bahan organik yang masuk dari kegiatan masyarakat. Meskipun belum cukup optimal membantu pengurangan limbah tetapi dengan kadar DO yang masih berada dalam rentang minimum yaitu sebesar $2 \mathrm{mg} / \mathrm{L}$, akan membantu keberlangsungan ikan-ikan dan binatang air lainnya yang membutuhkan oksigen tidak akan mati. Simulasi skenario 2 dilakukan dengan menggunakan kondisi yang dianggap tidak ada masukan dari sumber pencemaran air limbah atau lainnya dan kondisi kualitas air sebelumnya juga diasumsikan sudah memenuhi baku mutu untuk air sungai Kelas I. Simulasi ini dimaksudkan untuk mengetahui pengaruh yang tidak mempunyai sumber pencemaran 
terhadap kualitas air sungai di setiap titik hingga hilir. Hasil simulasi skenario 2 dapat dilihat pada gambar 4.

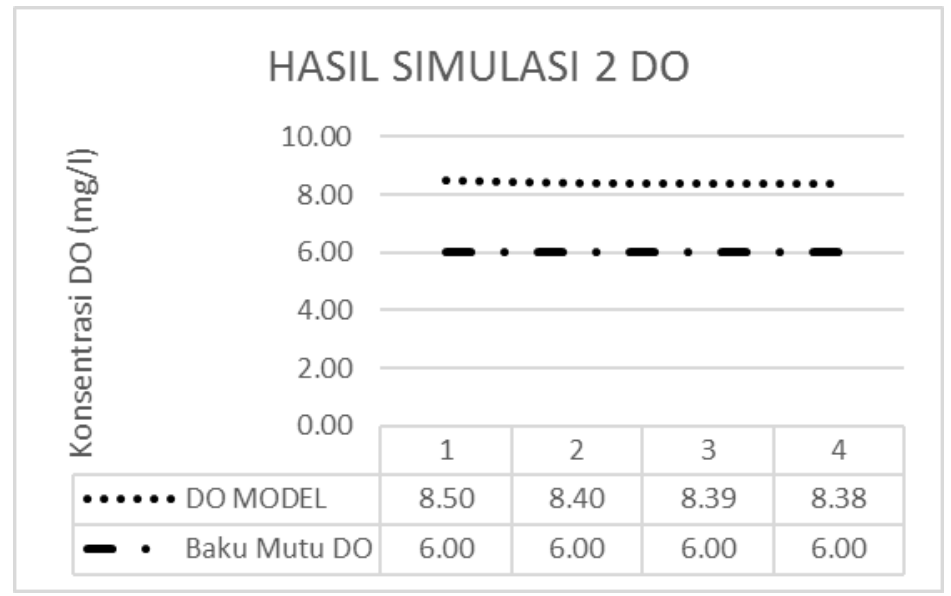

Gambar 4. Hasil Simulasi 2 DO

Hasil analisis konsentrasi DO pada hasil simulasi 2 menunjukkan peningkatan DO yang memenuhi baku mutu air kelas I. Peningkatan konsentrasi DO menandakan bahwa air Sungai Tapin telah mengalami pengurangan beban pencemaran limbah oleh bahan organik yang masuk dari kegiatan masyarakat. Karena pada simulasi ini beban pencemaran yang masuk dianggap sudah diolah terlebih dahulu menggunakan IPAL sehingga tidak ada sumber pencemar yang masuk. Konsentrasi DO yang sudah melebihi 6 sudah cukup optimal membantu pengurangan limbah dan membantu keberlangsungan ikan-ikan dan binatang air lainnya yang membutuhkan oksigen tidak akan mati.

\subsection{Pembuatan Model BOD}

Parameter BOD digunakan sebagai data untuk melakukan simulasi menggunakan HEC-RAS berdasarkan kondisi hidrolika, kualitas nutrien air sungai dan meteorologi di lokasi penelitian. Pembuatan model diawali dengan memasukkan data dalam program HEC-RAS yaitu membuat projek baru yang dinamai sesuai dengan kebutuhan, selanjutnya adalah membuat peniruan geometri saluran atau air sungai yang diikuti dengan peniruan jenis aliran sungain yang berupa aliran steady flow. Pada program ini data kualitas air diinput dengan memilih menu utama "edit water quality boundary conditionI” serta pilihan koefisien kualitas air untuk menjalankan program.

Hasil dari simulasi kualitas air parameter BOD perlu dilakukan tahap kalibrasi yang ditentukan oleh koefisien dari masing masing parameter dengan cara memasukkan nilai dari $\mathrm{K}_{1}$ (Decay Rate) dan $\mathrm{K}_{2}$ (Atmospheric Reaeration) pada lembar kerja nutrient parameters. Hal ini bertujuan untuk menyamakan hasil simulasi model parameter BOD dengan hasil pengukuran di lapangan. Data hasil pengukuran dan data hasil pemodelan HEC-RAS menunjukkan besar konsentrasi BOD di Sungai Tapin sama-sama berasal dari sumber pencemar limbah kegiatan domestik dan MCK masyarakat. Pada hasil pemodelan ini dilakukan validasi untuk membandingkan antara hasil pemodelan menggunakan HEC-RAS dengan nilai hasil pengukuran di lapangan. Validasi dilakukan menggunakan metode Root Mean Square Error (RMSE) untuk menunjukkan hasil dari pemodelan dengan hasil yang akan dimodelkan. Perhitungan 
dengan program HEC-RAS dapat dilihat pada Tabel 3.3. Lokasi yang digunakan untuk memvalidasi model adalah lokasi yang dekat dengan pengukuran langsung.

Tabel 3.3 Hasil Pengukuran dan Perhitungan HEC-RAS Konsentrasi BOD

\begin{tabular}{|c|c|c|c|}
\hline $\begin{array}{c}\text { Waktu } \\
\text { Pengamatan }\end{array}$ & $\begin{array}{l}\text { Titik Lokasi } \\
\text { Pengamatan }\end{array}$ & $\begin{array}{c}\text { Hasil Pemodelan } \\
(\mathrm{mg} / \mathrm{l})\end{array}$ & $\begin{array}{c}\text { Hasil Pengukuran } \\
(\mathrm{mg} / \mathrm{l})\end{array}$ \\
\hline \multirow{2}{*}{8 Agustus 2018} & 1 & 1.29 & 1.533 \\
\hline & 2 & 1.09 & 1.185 \\
\hline \multirow{2}{*}{$\begin{array}{c}(09.00-11.10 \\
\text { WITA })\end{array}$} & 3 & 1.09 & 1.185 \\
\hline & 4 & 1.09 & 0.488 \\
\hline \multicolumn{2}{|c|}{ Root Mean Square Error (RMSE) } & \multicolumn{2}{|c|}{0.02} \\
\hline
\end{tabular}

Berdasarkan Tabel 3.3 terlihat hasil pemodelan di titik 1 sebesar 1,293 mg/l sedangkan hasil pengukurannya sebesar $1,533 \mathrm{mg} / \mathrm{l}$, titik 2 terlihat hasil dari pemodelan sebesar $1.091 \mathrm{mg} / \mathrm{l}$ sedangkan hasil pengukurannya sebesar $1,185 \mathrm{mg} / \mathrm{l}$. Hasi model di titik 3 dan 4 adalah sama-sama mempunyai nilai sebesar 1,090 mg/l sedangkan hasil dari pengukuran titik 3 sebesar 1,185 dan titik 4 sebesar 0,488 $\mathrm{mg} / \mathrm{l}$. Adapun kondisi simulasi konsentrasi BOD merupakan simulasi yang sesuai dengan kondisi eksisiting saat Tahun 2018, dimana data yang diinput sesuai dengan hasil dari pembentukan model. Lalu dilakukan running pada program HEC-RAS. Dalam penelitian ini hanya dilakukan perhitungan model pada pagi hari. Parameter kualitas air yang disimulasi adalah BOD, adapun simulasi kualitas air Sungai Tapin dilakukan sebanyak 2 skenario dengan asumsi debit, kualitas air di hulu (Desa Bungur), kondisi sumber pencemaran, dan kualitas air di sepanjang sungai. Simulasi skenario 1 dilakukan dengan menggunakan kondisi sumber pencemaran hasil dari pemodelan yaitu data air limbah dan sumber pencemar lainnya berdasarkan data Tahun 2018. Simulasi ini dimaksudkan untuk mengetahui pengaruh sumber pencemaran eksisting terhadap kualitas air sungai di setiap titik hingga hilir. Hasil simulasi skenario 1 dapat dilihat pada gambar 5.

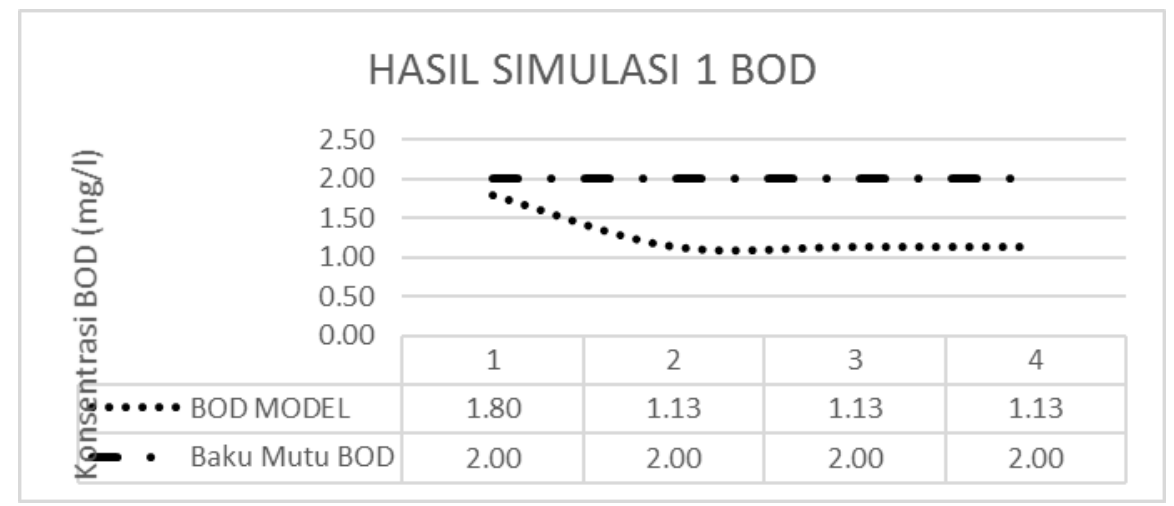

Gambar 5. Hasil Simulasi 1 BOD

Nilai BOD model, pengukuran lapangan dan simulasi 1 selalu mengalami penurunan konsentrasi yang menunjukkan bahwa air Sungai Tapin dari arah hulu ke hilir cenderung mengalami pengurangan beban pencemaran limbah oleh bahan organik yang masuk dari kegiatan masyarakat tetapi konsentrasi BOD hampir melampaui dari batas baku mutu yang ditetapkan. Hal tersebut sesuai dengan konsentrasi DO 
yang mengalami peningkatan untuk setiap titik lokasi. Hasil konsentrasi BOD dipengaruhi oleh adanya proses dekomposisi dalam jumlah yang sedikit sehingga meningkatkan jumlah oksigen terlarut (DO) yang dimodelkan lebih besar daripada hasil pengukuran. Simulasi skenario 2 dilakukan dengan menggunakan kondisi yang dianggap tidak ada masukan dari sumber pencemaran air limbah atau lainnya dan kondisi kualitas air sebelumnya juga diasumsikan sudah memenuhi baku mutu untuk air sungai Kelas I. Simulasi ini dimaksudkan untuk mengetahui pengaruh yang tidak mempunyai sumber pencemaran terhadap kualitas air sungai di setiap titik hingga hilir. Hasil simulasi skenario 2 dapat dilihat pada gambar 6 .

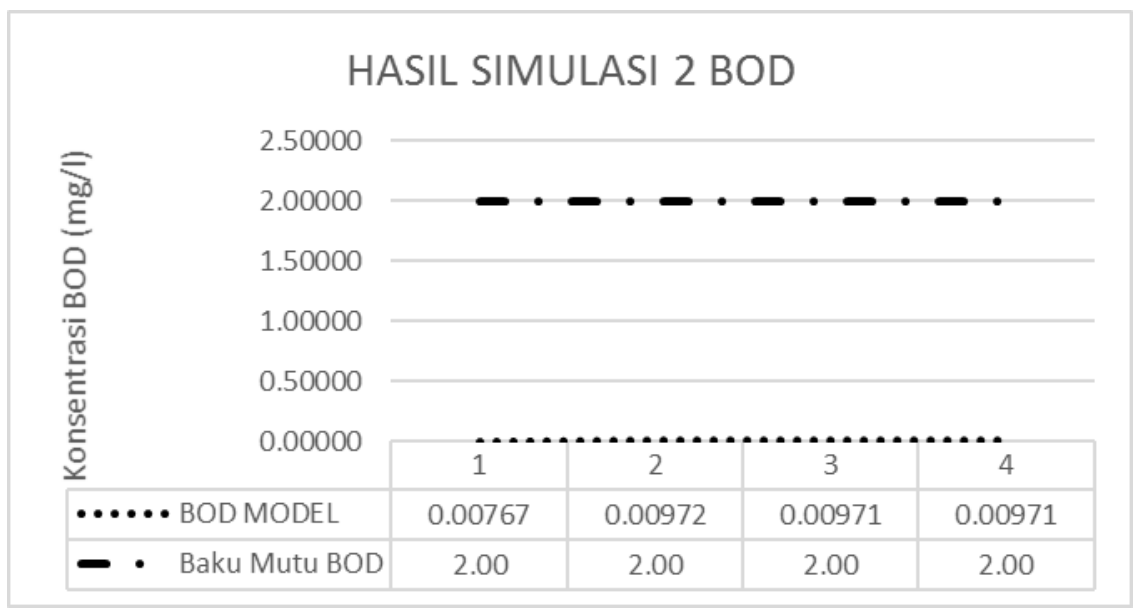

Gambar 6. Hasil Simulasi 2 BOD

Hasil analisis konsentrasi BOD pada hasil simulasi 2 menunjukkan penurunan BOD yang sudah memenuhi baku mutu air kelas I. Penurunan konsentrasi BOD menandakan bahwa air Sungai Tapin telah mengalami pengurangan beban pencemaran limbah oleh bahan organik yang masuk dari kegiatan masyarakat. Karena pada simulasi ini beban pencemaran yang masuk dianggap sudah diolah terlebih dahulu menggunakan IPAL sehingga tidak ada sumber pencemar yang masuk. Menurut Salmin (2005) air Sungai Tapin termasuk dalam kategori perairan yang mengandung BOD kurang cukup baik dalam hal membantu proses penguraian limbah organik karena mempunyai kadar BOD kurang dari 1-10 ppm.

\subsection{Perhitungan Daya Tampung beban Pencemaran}

Daya tampung beban pencemaran air berbeda dengan beban pencemaran karena beban pencemaran adalah jumlah suatu unsur pencemar yang terkandung dalam air maupun limbah yang dapat disebabkan oleh adanya aktivitas industri, pemukiman dan pertanian. Sedangkan kemampuan air sungai untuk menerima masukan pencemaran tanpa menyebabkan air tersebut tercemar disebut dengan daya tampung beban pencemaran (BPDT). Apabila besaran beban pencemaran sungai melebihi daya tampung beban pencemaran sungai itu sendiri maka yang terjadi adalah sungai tersebut menjadi tercemar (Hendriarianti, Setyobudiarso, \& Triono, 2014). Perhitungan beban pencemaran Sungai Tapin dipengaruhi oleh debit air sungai dan dapat dilihat pada Tabel 3.4. Dari hasil perhitungan pada Tabel 3.4 dapat disimpulkan bahwa beban pencemaran Sungai Tapin yang terbesar ditunjukkan oleh parameter DO sebesar 6038,76 Kg/hari pada model simulasi ke 2. Sedangkan beban pencemaran terendah ditunjukkan oleh parameter BOD sebesar 6,62 Kg/hari pada model simulasi ke 2. Beban 
pencemaran DO yang tinggi dan BOD yang rendah disebabkan karena adanya berbagai kegiatan dan membuang limbah yang dihasilkan langsung ke badan Sungai Tapin diantaranya kegiatan pemukiman.

Tabel 3.4 Beban Pencemaran DO dan BOD Sungai Tapin

\begin{tabular}{ccccccccc}
\hline $\begin{array}{c}\text { Titik } \\
\text { Sampel }\end{array}$ & $\begin{array}{c}\text { BOD } \\
\text { EKSISTING }\end{array}$ & $\begin{array}{c}\text { BOD } \\
\text { MODEL }\end{array}$ & $\begin{array}{c}\text { BOD } \\
\text { EIMULASTING }\end{array}$ & $\begin{array}{c}\text { BOD } \\
\text { SIMULASI }\end{array}$ & $\begin{array}{c}\text { DO } \\
\text { EKSISTING }\end{array}$ & $\begin{array}{c}\text { DO } \\
\text { MODSL }\end{array}$ & $\begin{array}{c}\text { DO } \\
\text { SIMULASI }\end{array}$ & $\begin{array}{c}\text { DO } \\
\text { SIMULASI }\end{array}$ \\
\hline 1 & 266.07 & 224.48 & 312.49 & 1.33 & 640.44 & 761.85 & 707.50 & 1475.06 \\
2 & 168.66 & 155.50 & 161.53 & 1.38 & 604.91 & 675.07 & 756.94 & 1195.78 \\
3 & 231.10 & 212.89 & 221.18 & 1.89 & 756.69 & 951.09 & 1056.09 & 1635.69 \\
4 & 100.89 & 225.58 & 234.43 & 2.01 & 800.13 & 1026.11 & 1132.56 & 1732.24 \\
Jumlah & $\mathbf{7 6 6 . 7 3}$ & $\mathbf{8 1 8 . 4 5}$ & $\mathbf{9 2 9 . 6 2}$ & $\mathbf{6 . 6 2}$ & $\mathbf{2 8 0 2 . 1 6}$ & $\mathbf{3 4 1 4 . 1 2}$ & $\mathbf{3 6 5 3 . 0 9}$ & $\mathbf{6 0 3 8 . 7 6}$ \\
\hline
\end{tabular}

Beban pencemaran yang telah diketahui kemudian akan dihitung daya tampung beban pencemaran sungai dimana penetapan daya tampung merupakan palaksanaan pengendalian pencemaran air yang menggunakan pendekatan kualitas air. Hasil perhitungan daya tampung Sungai Tapin dapat dilihat pada Tabel 3.5 sebagai berikut:

Tabel 3.5 Daya Tampung Beban Pencemaran Sungai Tapin

\begin{tabular}{cccccc}
\hline \multicolumn{5}{c}{ Daya Tampung Beban Pencemaran Air Sungai Tapin Terhadap Parameter BOD } \\
\hline \multirow{2}{*}{ No } & \multirow{4}{*}{ Model } & \multicolumn{4}{c}{ Titik Pengambilan Sampel (Kg/hr) } \\
\cline { 3 - 6 } & & $\mathbf{1}$ & $\mathbf{2}$ & $\mathbf{3}$ & $\mathbf{4}$ \\
\hline 1 & Real & 81.05 & 116.00 & 158.94 & 312.61 \\
2 & Model Eks & 122.64 & 129.16 & 177.15 & 187.92 \\
3 & Model 1 & 34.63 & 123.14 & 168.86 & 179.08 \\
4 & Model 2 & 345.79 & 283.28 & 388.15 & 411.49 \\
\hline \multirow{2}{*}{ Jumlah Daya } & & & & \\
Tampung (Kg/hr) & $\mathbf{5 8 4 . 1 2}$ & $\mathbf{6 5 1 . 5 8}$ & $\mathbf{8 9 3 . 1 1}$ & $\mathbf{1 0 9 1 . 1 0}$ \\
\hline
\end{tabular}

Dari hasil perhitungan pada Tabel 3.4 dapat disimpulkan bahwa daya tampung beban pencemaran Sungai Tapin yang terbesar berada di titik 4 yaitu sebesar 1091,10 Kg/hari. Sedangkan daya tampung beban pencemaran terendah berada di titik 1 yaitu sebesar 584,12 $\mathrm{Kg} / \mathrm{hari}$. Berdasarkan hasil dari model eksisting, model simulasi ke 1 dan 2 daya tampung beban pencemaran BOD selalu berfluktuasi. Hal tersebut disebabkan karena meningkatnya konsentrasi BOD akibat masukan beban pencemaran domestik yang diiringi dengan berkurangnya daya tampung sungai terhadap beban pencemaran organik. Sedangkan rendahnya konsentrasi BOD disebabkan karena terjadinya proses aerasi dalam air sungai dan juga disebabkan oleh adanya pepohonan yang berada di tepi sungai sehingga membantu pengurangan limbah yang masuk. Sehingga daya tampung beban pencemaran terhadap beban organik juga akan meningkat. Oleh sebab itu, salah satu upaya dalam pengelolan sungai adalah mencari besaran daya tampung yang diterima oleh sungai (Marlina et al., 2015). 


\subsection{Strategi Pengendalian Pencemaran Air}

Strategi pengendalian pencemaran air merupakan upaya yang dilakukan dalam rangka pencegahan dan penanggulangan terjadinya pencemaran air serta pemulihan kualitas air sesuai kondisi alaminya sehingga kualitas air sungai terjaga sesuai dengan peruntukkannya. Demikian juga kebijakan pengendalian pencemaran Sungai Tapin yang diharapkan mampu mencegah terjadinya pencemaran air sehingga Sungai Tapin dapat dimanfaatkan sesuai dengan peruntukkannya. Berdasarkan hasil pengukuran dan pengamatan yang dilakukan, maka upaya pengendalian pencemaran untuk kebijakan yang berkelanjutan dan paling sesuai dengan kondisi Sungai Tapin menurut Yuliastuti (2011) adalah sebagai berikut:

1. Meningkatkan inventarisasi dan identifikasi sumber pencemar air

2. Meningkatkan Pengelolaan Limbah

3. Menetapkan Daya Tampung Beban Pencemaran

4. Meningkatkan Pengetahuan dan Partisipasi Masyarakat dalam Pengelolaan Limbah

5. Meningkatkan Pengawasan Terhadap Pembuangan Air Limbah

6. Meningkatkan Pemantauan Kualitas Air sungai

\section{KESIMPULAN DAN SARAN}

\subsection{KESIMPULAN}

Hasil pengukuran status mutu air pada ke-4 titik/lokasi pengambilan sampel menunjukkan status cemar ringan dengan menggunakan metode Indeks Pencemaran. Sehingga peruntukan untuk air Sungai Tapin sebagai air sungai Kelas I tidak sesuai dengan Peraturan Gubernur Kalsel No 5 Tahun 2007 sehingga besar daya tampung Sungai Tapin terhadap beban pencemaran organik pada Tahun 2018 adalah sebesar 616,88 Kg/hari dengan daya tampung beban pencemaran tertinggi terdapat di titik 4 sebesar $187,92 \mathrm{Kg} / \mathrm{hari}$ sedangkan daya tampung beban pencemaran terendah terdapat di titik 1 sebesar 122,64 $\mathrm{Kg} / \mathrm{hari}$

\subsection{SARAN}

Saran yang dapat diberikan dari penelitian ini adalah perlu penelitian lebih lanjut yang memperhitungkan konsentrasi kualitas nutrien perairan serta identifikasi sumber pencemaran yang masuk ke Sungai Tapin dan perhitungan besaran debit air limbah yang dihasilkan dari setiap kegiatan masyarakat setempat. Selain itu, perlu adanya penelitian lebih lanjut mengenai upaya pengendalian pencemaran Sungai Tapin dengan menggunakan metode analisis seperti SWOT atau AHP untuk mengetahui faktor internal dan eksternal pencemaran air.

\section{DAFTAR PUSTAKA}

Allbab, U., Dermawan, V., \& Harisuseno, D. (2015). Studi Analisis Nilai Sebaran Kadar Oksigen Terlarut Dalam Aliran (DO) Pada Hulu dan Hilir Bangunan Bendung Di Daerah Irigasi Tumpang Kabupaten Malang.

Dinas Lingkungan Hidup Tapin. (2015). Laporan Kinerja Instansi Pemerintah Badan Lingkungan Hidup Kabupaten Tapin.

Dinas Lingkungan Hidup Tapin. (2017). Laporan Hasil Uji Kualitas Air Laboratorium Dinas Lingkungan Hidup Kabupaten Tapin. 
Hadi, A. (2015). Pengambilan Sampel Lingkungan. Erlangga. Jakarta.

Hendriarianti, E., Setyobudiarso, H., \& Triono, R. E. (2014). Skenario Pengelolaan Kualitas Air Sungai Metro Kota Malang Dari Analisa Daya Tampung Beban Pencemaran. Jurnal Purifikasi, 14(2), $125-135$.

Istiarto. (2014). Modul Pelatihan Simulasi Aliran 1-Dimensi Dengan Bantuan Paket Program Hidrodinamika Hec-Ras Jenjang Dasar: Simple Geometry River. Universitas Gadjah Mada. Yogyakarta.

Marganingrum, D., Djuwansah, M. R., \& Mulyono, A. (2018). Penilaian Daya Tampung Sungai Jangkok dan Sungai Ancar Terhadap Polutan Organik (Assessment of Jangkok and Ancar River Asimilative Capacity to Organic Pollutant). Jurnal teknologi Indonesia, 19(1), 71-80.

Marlina, N., Kasam, \& Juliani, A. (2015). Evaluasi Daya Tampung Terhadap Beban Pencemar Menggunakan Model Kualitas Air (Studi Kasus: Sungai Winongo). Jurnal Inovasi dan Kewirausahaan, 4(2), 78-86.

Mulla, R. K., \& Bhosale, S. M. (2015). Modeling And Simulation Of Rivers-A Review. International Journal of Innovative Research and Creative Technology, 1(3), 2454-5988.

Salmin. (2005). Oksigen Terlarut (DO) Dan Kebutuhan Oksigen Biologi (BOD) Sebagai Salah Satu Indikator Untuk Menentukan Kualitas Perairan. Jurnal Oseana, 30(3), 21-26.

SNI. Air dan air limbah - Bagian 57: Metoda pengambilan contoh air permukaan (2008).

Yuliastuti, E. (2011). Kajian Kualitas Air Sungai Ngringo Karanganyar dalam upaya Pengendalian Pencemaran Air. Tesis Program Pascasarjana Magister Ilmu Lingkungan. Universitas Diponegoro. Semarang. 
JTAM Teknik Lingkungan Universitas Lambung Mangkurat, Vol 3 (1) Tahun 2020

\section{halaman ini sengaja di kosongkan}

